\title{
The Influence of Work-from-home on job performance during COVID-19 pandemic: Empirical evidence Hanoi, Vietnam
}

\author{
Le Ha Anh and Nguyen Minh Trang \\ Department of Business Management \\ National Economic University \\ Hanoi, Vietnam \\ \{lehaanh02112001 \& \\ minhhtrang2312\}@gmail.com
}

\author{
Nguyen Thi Phuong Linh \\ Department of Business Management \\ National Economic University \\ Hanoi, Vietnam \\ linhnp@neu.edu.vn
}

\begin{abstract}
Many enterprises have been forced to change from office work to work-from-home (WFH) so as to protect their staff from COVID-19 pandemic. This study examines the impacts of the work-from-home (WFH) on employee's job performance (JP) as well as the mediate influence of three factors: Work environment (WE), Job satisfaction (JS) and Work-family conflict (WFC). A qualitative research methodology is adopted by interviewing 10 employees who have been working from home due to the impact of the COVID-19 epidemic in 8 different companies in Hanoi, Vietnam to understand their experiences of how WFH has impacted their job performance and learning outcomes. The result is that WFH has a negative and direct influence on job performance. Work-from-home has both positive and negative impacts on the work environment of employees. Although WFH employees are satisfied with some aspects, they seem to have both positive and negative effects on their job performance. Moreover, strain-based conflict primarily doesn't influence job performance when staff work at home. The study examines impacts on employee performance working from home as a result of the epidemic. There are some recommendations and notes proposed for improving the quality of WFH in the future.
\end{abstract}

Index Terms -Work - from - home, job performance, work environment, job satisfaction, work - family conflict.

\section{INTRODUCTION}

$\mathrm{S}$ ARS-CoV-2 is known as the seventh human coronavirus causing a global pandemic, which was first discovered in Wuhan, China in December 2019. Ref. [1] has updated that as of 5 November 2021, COVID-19 has infected 248.467.363 people and caused 5.027.183 deaths in the world. On 4 November 2021, a total of 7.027.377.238 vaccine doses were administered. The current outbreak has led to a great economic crisis across the whole continent and has readjusted how and where people work. Large numbers of cities were in lockdown, many businesses had been forced to close temporarily and employees had to stay at home due to social distancing policy. Facing the fear of infection and social distancing restriction, a rise in work - from - home (WFH) is inevitable.

From a business context, organizations had to identify the new procedure to assure employees' productivity while working remotely. Since the epidemic had spread, numbers of working from home research papers were taken by Ref. [2]; [3]; [4]; [5]. In Vietnam, the productivity of workers working from home has been a currently rising concern during the outbreak. However, a few authors did some research on this topic.

The purpose of the article is to provide insights into how workers feel about their performance when working from home during the COVID-19 period. By using a qualitative approach, this article also provides the mediating factors in the relationship between work from home (WFH) and job performance (JP): work environment (WE), job satisfaction (JS), and work-family conflict (WFC). Then, solutions to improve individuals' performance would be recommended at last.

\section{Literature ReVIEW}

\section{A. Work-from-home}

From "Working from home - What is the Effect on Employees' Effort?", Ref. [6] collected that WFH is classified into two main aspects. Firstly, employees work outside the casual office. Secondly, there is a connection between home and workplace. Colleagues interchange information and communicate with each other by using information and communications technology ([7]; [8]). Today, "work - from - home" became more common in COVID 19 period. According to Ref. [9], WFH could be generally defined as workers working outside the office. It includes 4 basic characteristics: (1) an employee of a company or a staff of an organization; (2) engage in specific tasks with a company or an organization; (3) perform their work outside the physical workplace and (4) telecommunication with the boss.

In this article, the authors use the term of WFH from previous studies and clarify about the work location during social distancing restriction: "WFH happens when an employee of a company or a staff of an organization performs tasks at their home; using telecommunication to connect and exchange information with their employers".

In the period from 1980 to 2010 , work from home started to emerge and become popular in developed 
countries such as America, Germany, England, Australia, ... The number of people working remotely has grown significantly since COVID-19 pandemic spread at the beginning of 2020 ([10]; [11]; [12]). According to the ILO report, more than four out of five people (81 per cent) in the global workforce of 3.3 billion are currently affected by full or partial workplace closures; therefore, working from home is a temporary safety solution in the epidemic situation, contributing to controlling the infection rate as well as maintaining work. Many forecasts also showed that this WFH still increased even after the pandemic ([13]; [14]). The effects of working - from - home are also a topic of interest and concern for many researchers, the positive effects of WFH research and negative effects in the study of Ref. [15]; [16]; [17]; [18]...

\section{B. Job Performance}

Ref. [19] defined job performance as the net effect of one's efforts simplified by these abilities and characteristics and by his perception of the role. This concept emphasizes that performance in a given scenario is the consequence of interrelationships between effort, talents, and qualities, as well as role perceptions. Ref. [20] argued that results must be explained from two perspectives: behavior and outcomes. From a behavioral point of view, job performance refers to what employees do or how they behave during work. From the outcome point of view, JP refers to the outcome of the employee's behavior. The definition used by the authors in this study is based on the similar research of Ref. [21]: Job performance is the employee's ability to complete works and tasks to achieve organization's goals within a certain period.

After investigating related studies on job performance, the authors chose six criteria based on Ref. [22], with a slight modification to fit the subject and scope of this article: (1) Quantity of work; (2) Quality of work; (3) Punctuality; (4) Attitude; (5) Reliability; and (6) Cooperation.

\section{The impact of Work-from-home on Job Performance}

According to Ref. [2], WFH assists employees in increasing their enjoyment of work, job satisfaction, and motivation. Job satisfaction is one of the most important aspects of an employee's ability to execute given responsibilities successfully. Furthermore, as long as there is an Internet connection, employees may readily access work from wherever. Whereas the Covid-19 epidemic has not been completely controlled WFH would limit their mobility to lower the chance of infection. Ref. [4] studied the effectiveness of working from home in Canada and showed that 90 percent of the new teleworkers reported being at least as productive, i.e., doing at least as much work per hour at home as they did previously at their customary workplace. More than half $(58 \%)$ reported doing approximately the same amount of work per hour, while about $32 \%$ reported doing more work per hour.
However, it appears that WFH would not always be effective. Ref. [5] showed that WFH adversely affected employee performance. Ref. [3] provided pros and cons of WFH. On the positive side, WFH assists instructors in changing their working environment, particularly when they have become bored while working in the office, and work productivity has grown dramatically., perform the prescribed duties more rapidly. On the negative side, the authors demonstrate that WFH affects work productivity; for example, teachers will easily lose motivation while working because, in the end, the working environment at home will not be quite similar to the work environment at the office; distracted by social media or other forms of entertainment.

\section{The impact of Work-from-home on Work Environment}

Ref. [23] argued that working from home creates a flexible environment as freely scheduled arrangement and customization on work environment. Working from home, in particular, gives workers greater location flexibility. Another consideration is schedule flexibility. Work scheduling, flexible time, flexible work schedules, and schedule management are all synonyms for schedule flexibility. Meta-analytic studies have demonstrated that schedule flexibility is associated with many positive outcomes such as employee productivity, job satisfaction, and low absenteeism (Ref. [24]).

It suggests that working from home makes people feel more comfortable with their new work environment. They can be with their families while working and save money on commuting. The chance to spend time with their families is priceless, especially for those who work in the capital city. It gives the impression that they operate in a tailored work environment that is adaptable to their own personal preferences and lifestyle.

\section{E. The impact of Work-from-home on Job Satisfaction}

Many previous studies have concluded that working remotely has a positive effect, particularly, increases job satisfaction ([25]; [26]; [7]). Workers feel less pressured and have better external interaction control because there are no unexpected interruptions from managers and colleagues (Ref. [25]). Therefore, turnover rate decreases, and employees also feel more satisfied with their daily work. Although people working from home can use technologies such as video call and online meeting software, many believe that such devices have social and technological limitations (Ref. [27]) and "no technology can duplicate the experience of working onsite together" (Ref. [28]). In other words, JS may drop if people feel isolated from society and peers ([29]; [30]).

\section{F. The impact of Work-from-home on Work - family Conflict}

Many studies concluded that WFH helps people to reduce work - family conflict due to telecommunication 
bringing flexible time to manage work or family tasks (Ref. [31]). Ref. [32] applies role conflict theory, work stress models, and theories to directly connect work, family, and conflict. The study has concluded that three criteria Timebased conflict (T-WFC), Strain-based conflict (S-WFC) and Behavior-based conflict (B-WFC) with 4 out of 6 considered aspects of people working from home are lower than those working in the office. Although T-WFC and SWFC reduced when they worked at home, Ref. [32] didn't find the impact of Work-from-home on B-WFC.

Ref. [33] found that most of the studies on the relationship between work-from-home and family conflict use an interpersonal approach but more recent individual studies found that when working remotely on a daily basis, individuals experience less conflict between work and family than working in the office. This is also supported by Ref. [34]. The results of Ref. [35] also showed that daily work from home does not have a positive or negative impact on WFC while working overtime at home has a positive effect on WFC.

On the other side, many previous research papers have proven that working from home increases work-family conflict. Studies showed that teleworkers work longer hours and have more time pressure ([36]; [37]). Besides, Ref. [38] suggested that higher self-control may cause employees working from home to work overtime, crowding out housework. Another reason pointed out by Ref. [39] is that the use of mobile devices also reduces the separation between office work and personal work, leading to WFC.

\section{G. The impact of Work Environment on Job Performance}

Ref. [40] cited in his research that physical layout of workplace such as furniture, noise, light, temperature, comfort, security, air quality, casual and formal meeting rooms, available quiet spaces, privacy, working areas, etc.... impact on performance of employees. The reason is that a good comfortable working environment would improve performance and in contrast a bad working environment would decrease individuals' performance. Ref. [41] conducted research on the impact of the actual work environment on performance of officers: a situation of Putrajaya Malaysia Ministry of Youth and Sports. The result showed that physical environment (comfort and temperature) influences substantially on employee performance. This can be measured based on the percentage of working capacity per degrees Celsius in actual working environments in organizations. Ref. [42] showed fairly consistent results as they found an average relationship of a $2 \%$ reduction in job performance per degree Celsius when the temperature was above 25 degrees Celsius.

\section{H. The impact of Job Satisfaction on Job Performance}

Job satisfaction has a positive relationship with employees' performance because if employees are more satisfied and engaged in work, the results will automatically increase (Ref. [43]). Ref. [44] also showed that JS and JP are directly related, that is, if the satisfaction level is high, the job performance will also be good and vice versa.

However, research results of Ref. [45] in Parador hotels and resorts found that job satisfaction does not have an important role but only positive effect on the employee's work results, which means employee performance is not determined by job satisfaction. JS is not a necessary factor to promote JP because they believe that JS is not yet optimal. Ref. [46] in the study on "Evaluating the influence of working from home on job performance" in Indonesia also found that job satisfaction did not have a supportive relationship or not. important to job results.

In Vietnam, there were 547 employees in Vietnamese enterprises (Ref. [47]) and 325 employees in Ho Chi Minh City (Ref. [21]) working from home. The research was conducted in the context of the COVID-19 epidemic and both came to the conclusion about the positive and important influence of job satisfaction on employee's job results.

\section{The impact of Work - family Conflict on Job Performance}

According to Ref. [48], the association between work family conflict and performance is significant but negative. The study showed that the lack of support for the WFC appears to pose a major efficiency risk. This suggests that work-family conflict has an important link with success (Ref. [49]). Ref. [50] showed that work-family conflict has a great and negative impact on employee work performance, especially in the context of the ongoing COVID19 pandemic in this country.

In addition to the previous finding, several research studies have shown no association between WFC and employee performance. Ref. [51] discovered a substantial relationship between work-family conflict and job performance, and the study of Ref. [52] followed suit. the same, comparable.

Although most research has determined that this association is negative and substantial, Ref. [53] contends that conflict can have both good and negative consequences. Ref. [54] holds a similar viewpoint, stating that conflict may have a beneficial or detrimental influence on an individual's life. Conflict's influence may be defined as an inverted Ucurve, with low-intensity conflict having a beneficial impact on work performance. According to Ref. [54], high-intensity conflict creates stress and lowers human efficiency or work performance.

\section{METHODS}

\section{A. Data Collection}

To check the appropriateness of the factors and control variables, the authors choose to use an in-depth interview qualitative method. The authors inherited the factors and 
observations from previous studies, partly from studies conducted at foreign institutions and only a few domestic studies. Therefore, the author's team believes that conducting in-depth interviews with employees at enterprises in Vietnam is necessary. Employees, who work from home in Vietnam, experienced and have been experiencing work-from-home, have a thorough understanding of work and family life so that they will have reasonable statements about the suitability of variables. From the data collected, the team will draw factors that are suitable for the conditions in Vietnam. The authors conducted in-depth interviews with 10 employees who have been working from home due to the impact of the COVID19 epidemic in 8 different companies in Hanoi. TABLE 1 is the personal information of those 10 employees.

\section{B. Data Analysis}

The authors proposed in-depth open-ended questions based on statements of different previous quantitative research. In detail, questions about work-from-home, job performance and work environment were referred from Ref. [2]. We majorly measured five aspects of job satisfaction including work, supervision, wage, promotion and coworker, which were based on Ref. [55]. According to Ref. [32], questions about WFC will mention Time-based conflict (T-WFC), Strain-based conflict (S-WFC) and Behavior-based conflict (B-WFC).

TABLE 1

PROFILE OF RESPONDENTS

\begin{tabular}{|l|l|l|l|l|l|l|}
\hline $\begin{array}{c}\text { La- } \\
\text { bel }\end{array}$ & Gender & Age & Status & $\begin{array}{l}\text { (ncome } \\
\text { month } \\
\text { (million } \\
\text { VND) }\end{array}$ & Position & $\begin{array}{l}\text { Employ } \\
\text {-ment }\end{array}$ \\
\hline S1 & Female & 26 & Single & $>15$ & Sale & $\begin{array}{l}\text { Full- } \\
\text { time }\end{array}$ \\
\hline S2 & Female & 20 & Single & $<5$ & $\begin{array}{l}\text { Human } \\
\text { Resource }\end{array}$ & $\begin{array}{l}\text { Part- } \\
\text { time }\end{array}$ \\
\hline S3 & Female & 28 & Married & $5-10$ & Sale & $\begin{array}{l}\text { Full- } \\
\text { time }\end{array}$ \\
\hline S5 & Male & 22 & Single & $<5$ & Sale & $\begin{array}{l}\text { Part- } \\
\text { time }\end{array}$ \\
\hline S7 & Female & 24 & Single & $5-10$ & Accountant & $\begin{array}{l}\text { Full- } \\
\text { time }\end{array}$ \\
\hline S6 & Female & 30 & Married & $>15$ & Marketing & $\begin{array}{l}\text { Full- } \\
\text { time }\end{array}$ \\
\hline Sale & 35 & Married & $10-15$ & IT & $\begin{array}{l}\text { Full- } \\
\text { time }\end{array}$ \\
\hline time
\end{tabular}

\begin{tabular}{|l|l|l|l|l|l|l|}
\hline S10 & Male & 20 & Single & $<5$ & $\begin{array}{l}\text { Customer } \\
\text { Care }\end{array}$ & $\begin{array}{l}\text { Part- } \\
\text { time }\end{array}$ \\
\hline
\end{tabular}

In general, the interview questions were designed by the author's team (TABLE 2), with the interview content focusing on issues:

- Work-from-home

- Job performance of employees in some companies.

- The influence of Work environment on job performance when employees work from home due to COVID-19 pandemic.

- The influence of Job satisfaction on job performance when employees work from home due to COVID-19 pandemic.

- The influence of Work - family Conflict on job performance when employees work from home due to COVID-19 pandemic.

TABLE 2

IN-DEPTH OPEN-ENDED QUESTION

\begin{tabular}{|c|c|}
\hline Label & Question \\
\hline Q1 & $\begin{array}{l}\text { Do you feel the quantity and quality of work when working } \\
\text { from home is different from working in the office? }\end{array}$ \\
\hline Q2 & $\begin{array}{l}\text { How do you feel your home workspace affects your work } \\
\text { results? }\end{array}$ \\
\hline Q3 & $\begin{array}{l}\text { Is there any problem related to the work environment that } \\
\text { distracts you when you work at home? }\end{array}$ \\
\hline Q4 & What role do you feel technology plays in your job success? \\
\hline Q5 & Do you feel energetic every day working-from-home? \\
\hline Q6 & $\begin{array}{l}\text { Is the supervision, wages and promotion opportunities when } \\
\text { working-from-home different from office work? Are you } \\
\text { satisfied with that supervision, wages and promotion? }\end{array}$ \\
\hline Q7 & $\begin{array}{l}\text { Do you think that interaction with colleagues has a significant } \\
\text { influence on job performance while working from home? }\end{array}$ \\
\hline Q8 & $\begin{array}{l}\text { If you can choose to work from home after the pandemic is } \\
\text { over, would you agree to choose it? Why? }\end{array}$ \\
\hline Q9 & $\begin{array}{l}\text { Are there any factors at work that you feel interfere with } \\
\text { family life or vice versa? }\end{array}$ \\
\hline Q10 & $\begin{array}{l}\text { Do you feel that your time spent with work and family is better } \\
\text { or worse when working from home than working in the office? }\end{array}$ \\
\hline Q11 & $\begin{array}{l}\text { When you experience strain at work while working from } \\
\text { home, do you feel your productivity decreases and vice versa? }\end{array}$ \\
\hline
\end{tabular}


Have you ever applied your problem-solving behaviors you Q12 use in your job to solve family problems or vice versa? If yes, did you feel effective with that approach?

\section{RESULTS}

\section{A. Theme 1: Work-from-home impacts Job Performance}

Most of participants agreed that Work-from-home negatively impacts on their job performance:

My performance when working at home is different from working at the office. Sometimes, when working from home, I delay the tasks more because of the manager's weak supervision. (S1)

Actually, it's much more effective for job performance if I can work offline since my kind of work is specific. (S4)

When I am at the office, I work more productively. (S3)

However, the remains didn't agree with that:

I feel no change in quantity and quality of tasks between working-from-home and working at the office. (S5)

I feel I can complete the job as well as what my manager expected during the time working-from-home. I still finish all the jobs my boss gave promptly and faultlessly. (S7)

\section{B. Theme 2: Work-from-home, Work Environment and Job Performance}

Most of respondents gave statements that they like their workspace at home:

Work environment has a significant influence on my attention to work and my ability of creation. (S2)

I feel convenient and familiar with working at my own house. (S3)

I can finish my work faster when working from home because I want to do other stuff such as doing chores or my hobby. (S10)

But they reported that work environment at home negatively influence their job performance, especially the sound:

The home space is comfortable. However, it isn't a true work environment. The space is much narrower than the office and I have to lie on my bed to work. That is difficult for me to keep focusing on work for hours. (S1)

There are a lot of factors which can distract my concentration when working at home like TV sounds, chores, relatives,pets,... (S4)

...Children are the biggest distraction in my work environment when I work at home. (S6)

The problem of sound around my house strongly affects my job performance. For example, the soundproof of my house is not good so I can hear clearly honking sounds on the street, the talking sound of other people in my family as well as my neighbors,... That annoys me while working at home. (S9)

Some remarkable statements about technology given:
...Technology plays a key role in supporting me completing tasks exactly and quickly when I work at home. (S8)

Thanks to the Internet, I can connect and communicate with my colleagues, who give me a lot of motivation while I feel tired of working alone in my house. (S7)

...However, I am confused by using technology not only for working purposes but also solving personal problems or simply surfing social networks such as Facebook, Instagram,...because there is no one controlling me at home as strictly as at offices. (S8)

\section{Theme 3: Work-from-home, Job Satisfaction and Job Performance}

Some of the participants gave opinion about work/tasks:

Working- from-home: My boss gives me less quantity of work than working offline. I'm satisfied with that.(S9)

I receive less work at home from my manager because some tasks in my job can't be finished without meeting face to face. (S4)

I am satisfied with the quantity and quality of work when working-from-home and it's the same as when I go to work. (S10)

There are two main kinds of viewpoint about the loosened supervision:

Manager can't supervise as tightly as at the office because we only interact through a smart device. It must be hard for him even if he wants to improve his control. However, I feel better with this controlling level. I can arrange my work more flexibly... (S7)

Although the supervision loosened compared to working offline makes me happy, I feel that there is a delay in my mind, which prevents me from working punctually...(S6)

They gave different statements about wage:

They cut down on my wage when I must stay at home working due to social distance and I am really dissatisfied with that although I know it deserves the quantity of tasks they give me at this time. (S6)

My salary wasn't cut down, which makes me happy because I know many employees have been cut down or even received no wage during this period. Therefore, my job performance at home is more effective than at the company. (S5)

Some of the respondents's opinions about promotion:

There is no change in promotion opportunities. However, it doesn't seem to impact my job performance. (S3)

As I see, it's a bit easier for me and my colleague to be promoted when we work from home. (S7)

Some of their viewpoint about co-workers:

I can only communicate with my co-workers through a laptop or smartphone. Therefore, the quality of interaction has been limited. However, I'm satisfied with that because I 
know this limitation is to protect us from COVID-19 pandemic. (S8)

It is essential for me to keep in touch with my colleagues during working hours. I need their support to complete tasks faster and more effectively. (S10)

There are a lot of smart apps today allowing us to see and hear other people obviously like in a meeting such as Google Meet, MS Teams...So I don't feel isolated when working-from-home. (S9)

It takes me some minutes to hours to wait for them to reply to my message about work. That's a waste of time and a weakness of work-from-home. I don't like it, especially when I'm in a hurry at work, which negatively influences my performance. (S5)

Some of their feelings when they work from home:

I always feel energetic and comfortable during the period of working at home. (S2)

I am energetic everyday working at home because I no longer have to wake up to prepare and leave home early and go to one place only to start working. I can wake up at any time and work anywhere I want in my house as long as I complete the tasks on time. (S1)

I don't feel energetic every day. However, I can focus on work immediately after waking up. That's better than at the office where I usually hang out with my colleagues and do other errands before beginning working seriously. (S4)

Some of participants gave statements:

I will choose to work-from-home again because I'm used to it and my income is stable. (S1)

...I can make good use of time to do a lot of things rather than my tasks. (S5)

I prefer to work at the office because I don't worry much about COVID-19. I believe that the government has good policies to prevent the epidemic. (S3)

I choose to work offline because I want to interact and learn more skills and knowledge from my co-workers. (S4)

D. Theme 4: Work-from-home, Work - family Conflict and Job Performance

Some of the respondents said that they didn't have work-family conflict:

I definitely don't see any impact of work-family conflict on my daily life. I think the reason is that I haven't got children. (S1)

In fact, I don't usually face the work-family conflict even when I work at the office or at home. (S6)

Respondents who faced work - family conflict shared their personal feelings about time-based conflict:

Generally speaking, working at home improves the ability of balancing work and family. The working time is flexible and I can freely arrange time spent with family and work as long as I can complete all tasks to meet the deadline. However, sometimes, unexpected meetings will interfere with the time spent with family. (S2)
In my opinion, work-from-home is not as good as work at an office because I am distracted by worrying about my children. (S8)

I have my own tips to manage my timetable and obviously know when I should prioritise time for work or family. That's why I nearly avoid all work-family conflicts. (S1)

Some of participants gave statements about strain-based conflict:

If I am stressed with my work, I still handle the housework well. (S7)

When I am stressed with work at the office, my performance will be worse than I expected. But when I am in trouble with work at home, I still gain good performance because the environment in my house helps me relieve stress. Moreover, I don't need to face my boss or hear him grouse at that time - it's a big satisfaction to me. (S4)

When I quarrel with my partner or I am under pressure with the family responsibilities, I feel too exhausted to work so I will be late in the deadline or my quality of work will reduce. (S5)

Some of participants gave statements about behaviorbased conflict:

The problem-solving behaviors I use in my job are effective in resolving problems at home. (S8)

I sometimes apply the same problem-solving behaviors in work and family when I work from home and I feel it works well. (S3)

\section{DISCUSSION AND CONCLUSION}

As the results noted above, work-from-home have a negative and direct influence on job performance. The sudden change in working method from offline to online caused the reduction in employee's performance. There are two reasons why performance has been reduced when they work at home. Firstly, they become delayed with work because they haven't gotten used to considering their house as the second workplace instead of a relaxing place after working hours. Secondly, their work requires them to solve problems only at the office or by meeting face to face.

In general, work-from-home has both positive and negative impacts on the work environment of employees. They feel more convenient and familiar when working in their own house. They can work at any place they want such as the living room, bedroom and so on instead of sitting stably at one position in the office day by day, which improves their job performance. Moreover, technology is highly appreciated as a useful means supporting them to finish their tasks. By contrast, technology is also a serious distraction with employees when they work at home without supervision. They will be appealed to social networks like Facebook, Instagram with nonwork chats... rather than concentrate on the jobs. Another noteworthy factor of the work environment when they work at home is the sound. 
Everybody in a house has different things or activities to do, which don't focus only on work as at the office. Therefore, it is hard for employees to avoid hearing the sound from TV, from people talking, children shouting and playing and so on. Those negatively influence their concentration during working hours.

It can be seen that the quantity and quality of work employees receive when they work from home satisfies them whether it is reduced or not. It can be explained that they adapted to the quantity of work so they rarely have unexpected troubles handling them. Although employees are satisfied with manager's supervision, some of them show less effective job performance due to that. Therefore, supervision has an important influence on employees' job performance. About wages, they are really sensitive to this factor. Cutting down on their wages dramatically decreases their job satisfaction but it doesn't impact their job performance much because they know the serious influence of COVID-19 pandemic on their company. There is nearly no change in promotion when employees work at home. In addition, there is also no relationship between promotion opportunities and job performance. That's maybe because the period of working-from-home hasn't lasted long enough so they haven't seen the difference clearly. Thanks to technology, employees still can interact with their colleagues. Co-workers play an important role in their job performance. Sometimes, work-from-home dissatisfied employees about the quality and the time of interaction because they are not always online to answer every question immediately, which negatively affects their job performance.

With the respondents who manage their time well, they don't find the relationship of work-from-home, work-family conflict and their job performance. Work-from-home negatively affects work-family conflict, which means that the schedule becomes more flexible for them to arrange work and family activities in the order they want. The home space also helps them relieve stress. However, the flexibility also can increase work-family conflict because they easily lose control and spend too much time on one thing, which overwhelms the time for another. The findings show strainbased conflict primarily doesn't influence job performance when staff work at home. There is another interesting feature in the results that work-from-home has a negative but not significant relationship with work-family conflict in the behavioral aspect.

From the discussion above, we want to list some features that employers should notice to create suitable work-from-home policies for staff. They should have a policy related to technology, which keeps staff always ready to interact, receive and respond to information quickly and effectively. An increasingly tight policy of supervision will help to improve job performance. Employers also should care about providing a compensation policy which is enough to encourage and increase the satisfaction as well as the loyalty of their staff. Finally, a working time-limited method should be applied to prevent employees from overspending time on work or family which causes work-family conflict.

\section{RESEARCH LIMITATIONS}

This study has a limited scope of research in Hanoi, which is one of areas affected seriously by the epidemic in Vietnam. The number of participants in this qualitative research is also small and is not randomly chosen. Although authors collected data with some control variables such as age, education, income, position and so on, we haven't investigated how differences in those factors may influence the job performance of people who work from home, which may provide further insights into the phenomenon. Further studies should widen the scope of research as well as the number of samples to achieve more exact and reliable results.

\section{REFERENCES}

[1] WHO Health Emergency Dashboard https://covid19.who.int/

[2] Susilo, D. (2020). Revealing the Effect of Work-FromHome on Job Performance during the Covid-19 Crisis: Empirical Evidence from Indonesia. Journal of Contemporary Issues in Business and Government, 26(1), 23-40.

[3] Purwanto, A., Asbari, M., Fahlevi, M., Mufid, A., Agistiawati, E., Cahyono, Y., \& Suryani, P. (2020). Impact of work from home (WFH) on Indonesian teachers performance during the Covid-19 pandemic: An exploratory study. International Journal of Advanced Science and Technology, 29(5), 6235-6244.

[4] Mehdi, T., \& Morissette, R. (2021). Working from home: Productivity and preferences. StatCan COVID19: Data to Insights for a Better Canada. Available online at: https://www150. statcan. gc. ca, (1).

[5] Prodanova, J., \& Kocarev, L. (2021). Is job performance conditioned by work-from-home demands and resources?. Technology in Society, 66, 101672.

[6] Rupietta, K., \& Beckmann, M. (2016). Working from home: What is the effect on employees' effort? (No. 2016/07). WWZ Working Paper.

[7] Bélanger, France. 1999. Workers' propensity to telecommute: An empirical study. Information and Management 35(3): 139-153.

[8] Bailey, Diane E., and Nancy B. Kurland. 2002. A review of telework research: Findings, new directions, and lessons for the study of modern work. Journal of Organizational Behavior 23(4): 383-400.

[9] Savić, D. (2020). COVID-19 and work from home: Digital transformation of the workforce. Grey Journal (TGJ), 16(2), 101-104.

[10] Bartik, A. W., Cullen, Z. B., Glaeser, E. L., Luca, M., 
\& Stanton, C. T. (2020). What jobs are being done at home during the COVID-19 crisis? Evidence from firm-level surveys (No. w27422). National Bureau of Economic Research.

[11] Brynjolfsson, E., Horton, J. J., Ozimek, A., Rock, D., Sharma, G., \& TuYe, H. Y. (2020). COVID-19 and remote work: an early look at US data (No. w27344). National Bureau of Economic Research.

[12] Dubey, A. D., \& Tripathi, S. (2020). Analysing the sentiments towards work-from-home experience during covid-19 pandemic. Journal of Innovation Management, 8(1), 13-19.

[13] Bloom, N. (2020). The bright future of working from home. SIEPR blog.

[14] Analytics, G. W. (2020). What is your work-fromhome forecast for after Covid-19?.

[15] Kurland, N.B. and Cooper, C.D. (2002) Manager Control and Employee Isolation in Telecommuting Environments, Journal of High Technology Management Research,_13,_107-126.

[16] Gajendran, R.S. and Harrison, D.A. (2007) The Good, the Bad, and the Unknown About Telecommuting: Meta-Analysis of Psychological Mediators and Individual Consequences, The Journal of Applied Psychology,_92,_6,_1524-41.

[17] Scholefield, G. and Peel, S. (2009) Managers' Attitudes to Teleworking, New Zealand Journal of Employment Relations, 34,_3,_1-13.

[18]Hodder, A. (2020). New Technology, Work and Employment in the era of COVID-19: reflecting on legacies of research. New Technology, Work and Employment, 10.1111/ntwe.12173.

[19] Porter, L. W., \& Lawler, E. E. (1968). Managerial attitudes and performance.

[20] Campbell, J. P., McCloy, R. A., Oppler, S. H. and Sager, C. E. (1993) 'A theory of performance', in C. W. Schmitt and W. C. A. Borman (eds), Personnel Selection in Organizations. San Francisco: JosseyBass, pp. $35-70$

[21] Vuong, B. N. (2021). Ảnh hưởng của làm việc tại nhà đến hiệu quả công việc trong bối cảnh đại dịch covid19: Bằng chứng thực nghiệm tại Thành phố Hồ Chí Minh

[22] Ghozali, M., Zarkasyi, H. F., Jayanti, K. F., \& Wulandari, Y. (2019). Employee Performance Appraisal in Business.

[23] Baltes, B. B., Briggs, T. E., Huff, J. W., Wright, J. A., \& Neuman, G. A. (1999). Flexible and compressed workweek schedules: A meta-analysis of their effects on work-related criteria. Journal of applied psychology, 84(4), 496.

[24] Allen, T. D., Golden, T. D., \& Shockley, K. M. (2015). How effective is telecommuting? Assessing the status of our scientific findings. Psychological science in the public interest, 16(2), 40-68.

[25] Dubrin, A. J. 1991. Comparison of the job satisfaction and productivity of telecommuters versus in-house employees: A research note on work in progress. Psychological Reports, 68: 1223-1234.

[26] Norman, P., Collins, S., Conner, M., Martin, R., \& Rance, J. 1995. Attributions, cognitions, and copying styles: Teleworkers' reactions to work-related problems. Journal of Applied Social Psychology, 25(2): 117-128.

[27]Rice, R. E., \& Gattiker, U. E. 2001. New media and organizational structure. In F. Jablin \& L. Putnam (Eds.), Handbook of organizational communication: Advances in theory, research and methods: 544-581. Thousand Oaks, CA:Sage.

[28] Shapiro, D. L., Furst, S. A., Spreitzer, G. M., \& Von Glinow, M. A. 2002. Transnational teams in the electronic age: Are team identity and high performance at risk? Journal of Organizational Behavior, 23: 455467.

[29] Pool, I. 1990. Technologies without boundaries: On telecommunications in a global age. Cambridge, MA: Harvard University Press.

[30] Yap, C. S., \& Tng, H. 1990. Factors associated with attitudes towards telecommuting. Information and Management, 19: 227-235.

[31] Ten Brummelhuis, L. L., Bakker, A. B., Hetland, J., \& Keulemans, L. (2012). Do new ways of working foster work engagement?. Psicothema, 113-120.

[32] Madsen, S. R. (2003). The effects of home-based teleworking on work-family conflict. Human Resource Development Quarterly, 14(1), 35-58.

[33] Delanoeije, J., Verbruggen, M., \& Germeys, L. (2019). Boundary role transitions: A day-to-day approach to explain the effects of home- based telework on work-to-home conflict and home-to-work conflict. Human Relations, 72, 1-26

[34]Darouei, M., \& Pluut, H. (2021). Work from home today for a better tomorrow! How working from home influences work-family conflict and employees' start of the next workday. Stress and Health.

[35]Eng, W., Moore, S., Grunberg, L., Greenberg, E., \& Sikora, P. (2010). What influences work-family conflict? The function of work support and working from home. Current Psychology, 29(2), 104-120.

[36]Peters, P., \& Van der Lippe, T. (2007). The timepressure reducing potential of telehomeworking: The Dutch case. The International Journal of Human Resource Management, 18(3), 430-447

[37] Glass, J. L., \& Noonan, M. C. (2016). Telecommuting and earnings trajectories among American women and men 1989-2008. Social Forces, 95(1), 217-250.

[38] Sullivan, C., \& Lewis, S. (2001). Home-based telework, gender, and the synchronisation of work and 
family: Perspectives of teleworkers and their co-residents. Gender, Work and Organization, 8(2), 123-145.

[39] Mazmanian, M., Orlikowski, W. J., \& Yates, J. (2013). The autonomy paradox: The implications of mobile email devices for knowledge professionals. Organization Science, 24(5), 1337-1357.

[40] Ramli, A. H. (2019). Work environment, job satisfaction and employee performance in health services. Business and Entrepreneurial Review, 19(1), 29-42.

[41] Ismail, et al. 2010. The Influence of Physical Workplace Environment. Voice of Academia.

[42] Niemela, R., Hannula, M., Routio, S., Reijula, K., \& Railio, J. (2002). The effect of indoor air temperature on labour productivity in call centers: A case study. Energy and Builidng Journal. 34, 759-764.

[43] Velnampy, T. (2008). Job attitude and employees performance of public sector organizationsin Jaffna district, Sri Lanka. GITAM Journal of Management, 6(2), 66-73.

[44] Pushpakumari, M. (2008). The impact of job satisfaction on job performance: An empirical analysis. City Forum, 9(1), 89-105.

[45] Pawirosumarto, S., Sarjana, P. K., \& Gunawan, R. (2017). The effect of work environment, leadership style, and organizational culture towards job satisfaction and its implication towards employee performance in Parador Hotels and Resorts, Indonesia. International Journal of Law and Management.

[46] Hutajulu, R. S. Evaluating the impact of "work from home policy" on job performance (Study Case in Indonesia).
[47] Loan, L. (2020). The influence of organizational commitment on employees' job performance: The mediating role of job satisfaction. Management Science Letters, 10(14), 3307-3312.

[48] Karakaş, A., \& SAHIN, N. (2017). The relation between work family conflict and employee performance: a research on hotel employee. Sosyoekonomi, 25(32), 51-69.

[49] Geroda, M. K. B., \& Puspitasari, E. (2017). The impact of workfamily conflict toward job performance - the case of external auditor. The 3rd PIABC (Parahyangan International Accounting and Business Conference.

[50] Novitasari, D., Sasono, I., \& Asbari, M. (2020). Work-family conflict and worker's performance during Covid-19 pandemic: What is the role of readiness to change mentality. International Journal of Science and Management Studies (IJSMS), 3(4), 122-134.

[51] Netemeyer, R. G., Boles, J. S., \& McMurrian, R. (1996). Development and validation of work-family conflict and family-work conflict scales. Journal of Applied Psychology, 81, 400-410.

[52] Bhuian, S. N., Menguc, B., \& Borsboom, R. (2005). Stressors and job outcomes in sales: A triphasic model versus a linear-quadraticinteractive model. Journal of Business Research, 58, 141-150.

[53] Rivai, H., Sagala, E.J., 2011. Manajemen Sumber Daya manusia Untuk Perusahaan dari teori ke Praktik, Edisi Kedua, Jakarta: Rajawali Pers.

[54] Usman, H., 2013. Manajemen, Teori, Praktik, dan Riset Pendidikan, Edisi 4, Jakarta: PT. Bumi Aksar

[55] Smith, P.C., Kendall, L.M. and Hulin, C.L. (1969), The Measurement of Satisfaction in Work and Retirement, Rand McNally, Chicago, IL. 